\title{
From early pollen trapping experiments to the Pollen Monitoring Programme
}

\author{
Thomas Giesecke $\cdot$ Sonia L. Fontana $\cdot$ \\ Willem O. van der Knaap · Heather S. Pardoe • \\ Irena A. Pidek
}

Received: 19 February 2010/ Accepted: 7 June 2010

(c) The Author(s) 2010. This article is published with open access at Springerlink.com

\begin{abstract}
Pollen monitoring has become a standard investigation method for researchers in several disciplines; among them are Quaternary palynologists, who conduct experiments in order to gain insights that will help to interpret the content of pollen in sediments. A review of the literature shows how these experiments diversified during the 1920s and 1930s with an array of different research questions, ranging from pollination biology to hay fever studies. Quaternary palynologists gained renewed interest with the possibility of radiocarbon dating late Quaternary sediments and obtaining accumulation rates. Also, the comprehensive model of pollen deposition and the pollen budget studies by $\mathrm{H}$. Tauber encouraged researchers to conduct similar experiments using the same type of pollen trap, which became the main trapping device for Quaternary palynologists. The high precipitation in the tropics inspired the development of alternative designs. The
\end{abstract}

Communicated by F. Bittmann.

T. Giesecke $(\bowtie) \cdot$ S. L. Fontana

Albrecht-von-Haller-Institute for Plant Sciences, Department of Palynology and Climate Dynamics, University of Göttingen, Untere Karspüle 2, 37073 Göttingen, Germany

e-mail: Thomas.Giesecke@biologie.uni-Goettingen.de

W. O. van der Knaap

Institute of Plant Sciences and Oeschger Centre for Climate Change Research, University of Bern, Altenbergrain 21, 3013 Bern, Switzerland

\section{H. S. Pardoe}

Department of Biodiversity and Systematic Biology, National Museum Wales, Cathays Park, Cardiff CF10 3NP, UK

I. A. Pidek

Institute of Earth Sciences, University of Maria

Curie-Sklodowska, al. Krasnicka 2 c/d, 20-718 Lublin, Poland equipment used to assess the pollen content in the air has evolved from simple gravity devices to different types of apparatus using a vacuum pump or revolving rods that collect the pollen on impact. Silicone impregnated filters exposed perpendicularly to the wind can also yield a volumetric assessment and have proven useful in areas with a low content of pollen in the air. The literature review is followed by a brief account of the developments which established the basis for the formation of a group of scientists monitoring the pollen deposition at a network of sites using standard pollen traps, the Pollen Monitoring Programme (PMP). Over the last 15 years the network has collected a large dataset, which is now available to answer a number of research questions. A summary of selected regions and environments, for which pollen monitoring results are available, is provided to serve as a complement to the investigations mentioned above and to provide an overview that may stimulate new research.

Keywords Pollen accumulation rates · Pollen influx . Pollen monitoring · Airborne pollen .

History of pollen trapping $\cdot$ Pollen dispersal

\section{Introduction}

Investigations that aim to assist in the interpretation of fossil pollen diagrams are of major importance, as they provide the tools to reconstruct past environments. In this respect, much information has been gained from the collection of surface samples of lake sediments, mosses and soil. Studies monitoring the pollen content of air and deposition of airborne pollen have also given enormous insights. Early results of diverse trapping experiments and surface sample studies are summarized by Erdtman (1943). 
Since the 1950s, the related research objectives of determining the quantity of pollen in the air, the amount being deposited on the ground, and the proportions of pollen types on the ground have developed independently, but have often inspired each other. The prospect of using modern pollen deposition rates as analogues for past situations (Welten 1944; Davis et al. 1973; Hicks 1994) spurred the formation of the Pollen Monitoring Programme (PMP), which is a network of researchers who have agreed to monitor the pollen deposition using standardised traps.

The aim of this contribution is to provide an account of the history of pollen trapping experiments, highlighting a selection of devices that have been and are being used to trap pollen. This review is by no means comprehensive, but intends to provide an overview of past developments. A further intention is to introduce a selection of natural environments where pollen monitoring experiments are conducted as part of the PMP and which are included in several of the contributions in this volume.

\section{The beginnings of pollen trapping}

It is difficult to set a starting date for investigations on the quantity of pollen released by a plant, present in a volume of air, or deposited at a distance from the parent plant. Early aerobiologists like Miquel (1883), who reported on the amount of pollen in the air among other things, probably provided the first information. However, if the lecture by von Post at the 16th convention of Scandinavian naturalists in 1916 is taken as the birth hour of the quantitative study of pollen in late Quaternary deposits, then we must look to Hesselman as the pioneer of pollen trapping experiments. Following von Post's (1918) presentation, Hesselman raised the question of how to separate locally produced pollen from long distance transported pollen (Hesselman 1916; Davis 2000). While von Post pointed out the good match between the occurrence of a pollen type in surface samples and the regional presence of the parent tree, Hesselman (1919a) conducted a pollen trapping experiment designed to quantify long distance pollen deposition. Petri dishes were exposed for consecutive 24-h periods from mid May until the end of June 1918, on two light ships. The Petri dishes contained filter paper soaked in glycerine and were sheltered from the rain. The two light ships were situated in the Baltic Sea 30 and $55 \mathrm{~km}$ from the nearest shore and Hesselman reported a total of 16.2 and 8.82 pollen grains per $\mathrm{mm}^{2}$ over the period from mid May to the end of June. He argued that it is important to take account of this long distance component when reconstructing the spread of species. Moreover, he suggested that the expression of palynological results as absolute counts per sample, as was commonly done before von Post described the advantage of percentages, may be better suited to adjust for the long distance component. The idea was to devise threshold values for pollen accumulation rates (PAR) of different taxa that would indicate their local presence. Such threshold values were finally devised by Hicks (2001) for the distribution limits of Betula, Pinus and Picea in northern Finland and were applied to Holocene pollen diagrams by Seppä and Hicks (2006).

In 1919, under Hesselman's supervision, Malmström (1923) conducted similar pollen trapping experiments in a large mire complex in northern Sweden. Malmström placed his pollen trapping Petri dishes in different vegetation types and observed that most Pinus pollen was trapped in the pine woodland, although, due to the large amount of Betula pollen, this trap had the lowest percentage of Pinus pollen. On the other hand, absolute catches of Picea pollen were similar for all traps, while its percentage values varied between 8 and $27 \%$.

When Hesselman obtained his pollen trapping results, he realised that this information was also relevant to forestry research, and he also published the results in the communications of the State Institute of Experimental Forestry (Hesselman 1919b). In central Europe, much interest in pollen dispersal stemmed from questions on pollination and reproduction biology. Knoll (1932) conducted experiments to estimate the settling velocity of pollen grains and Pohl (1933) investigated the quantity of airborne pollen around a parent tree. Rempe (1937) repeated and extended Pohl's experiments, exposing cylinders mounted with film and coated with vaseline to measure the amount of impacting pollen, thus simulating the fertilisation of the stigma. Experiments with such impact traps showed that the pollen content of the air dropped away exponentially with increasing distance from the emitting Corylus shrub. However, sticky glass plates on the ground indicated that maximum pollen deposition only occurred at some distance away from the plant. A different pattern was observed with increasing distance from a dense stand. The highest pollen counts in impact traps were found 70 to $150 \mathrm{~m}$ away from the stand, while there was little decline in pollen deposition on the ground over the first $300 \mathrm{~m}$. To estimate long distance transport, pollen impact cylinders were set up on the island of Helgoland (Germany), situated $51 \mathrm{~km}$ from the mainland and $44 \mathrm{~km}$ from the nearest island. The most noteworthy result was the impact of 9.5 Quercus pollen grains per $\mathrm{mm}^{2}$ during a 3.5 day period, which should be sufficient for the fertilisation of an oak tree (Rempe 1937).

Scamoni (1955) started in 1933 to monitor airborne pollen at a forestry station in Eberswalde (Germany) using a microscope slide with an area of $4 \mathrm{~cm}^{2}$ coated with glycerine-gelatine. The slide was mounted vertically, under a roof, on a wind vane, $1.6 \mathrm{~m}$ above the ground, so that it would be always exposed in the direction of the wind. 
During the flowering seasons of the years 1933-1936 and in 1949, the microscope slides were changed daily. Comparison of the results with daily meteorological conditions showed that warmth generally initiated the flowering whereas precipitation and moisture reduced pollen emission or removed the emitted pollen from the air. In 1938 Scamoni set up the same type of pollen trap to study the pollination of Pinus and Picea along a height gradient in the Krkonoše/Karkonosze mountains along the border between the Czech Republic and Poland (Scamoni 1949). He observed that pollen was transported up and down the mountain, but due to the different times of flowering, pollination may only have been possible within an altitudinal belt of $200 \mathrm{~m}$. Pollen from distant sources was also frequently observed, so pollination from distant trees could not be excluded. He even recorded a pollen grain of Tilia on top of the highest peak at $1,600 \mathrm{~m}$.

The impact of pollen on vertical cylinders or horizontal plates is not only related to the pollen content of the air, but also to the wind speed at the sampling location. Erdtman (1937) experimented with vacuum cleaners to obtain a quantitative measure of the pollen content of the air. In 1937, he sampled the pollen content of the air with a vacuum cleaner on a voyage from Göteborg to New York and back. The vacuum cleaner contained a bag of filter paper that could be chemically dissolved and the pollen analysed. He found that the pollen content of the air was lowest in mid ocean and that the overall average of 6.6 pollen grains per $100 \mathrm{~m}^{3}$ during the journey was dwarfed by the approximately 18,000 pollen grains per $100 \mathrm{~m}^{3}$ measured from April to June at the top of the water tower in the city of Västerås, Sweden.

Bertsch (1935) monitored the daily pollen deposition during the years 1932, 1933 and 1934, to facilitate the interpretation of pollen diagrams. He used microscope slides with a $1 \mathrm{~cm}^{2}$ area covered with glycerine. By comparing pollen deposition with the local and regional flowering of trees, he was able to separate pollen transported from regional and long distance sources. Regional forest inventory data allowed him to compare average pollen proportions with the proportional abundance of forest trees. As the regional forest was dominated by Picea with some Abies and Fagus, Bertsch observed a rather good agreement between pollen percentages and proportional tree abundance, but found Abies to be under-represented.

During 1934 and 1935, Lüdi monitored the pollen deposition in the Davos valley in Switzerland, with the primary aim to collect information with regard to the observation that hay fever was reduced in this high altitude alpine valley (Lüdi and Vareschi 1936; Lüdi 1937a). For pollen traps, he used low rimmed glass cups with glycerine at the bottom. These were placed in the open and thus also collected the pollen in rain water. Lüdi was also interested in interpreting fossil pollen spectra and therefore also published the results with this focus (Lüdi 1937b). This publication, together with the results obtained by Bertsch (1935), was used for comparison in the interpretation of the first pollen accumulation reconstruction of the laminated sediments of Faulenseemoos by Welten (1944). Welten directed his attention towards the Late-glacial part of the sequence and directly related tree abundance to pollen abundance. However, when considering short term climate fluctuations during the Late-glacial, he proposed that climate change could directly control the amount of pollen produced, but a reaction through a change in population density would be too slow. Welten emphasised that the absolute pollen diagram offered new insights into vegetation history. He concluded that volumetric sampling is important for obtaining absolute pollen deposition values for comparison with modern pollen deposition, but in the absence of pollen deposition values for the tundra he had to turn to Aario's (1940) pollen counts per weight from samples in the Finnish tundra and the tree line.

In most of the pollen trapping experiments described above, the authors clearly stated that the exposed glass dishes or microscope slides were protected from rain. In contrast, Firbas and Sagromsky (1947) reported on a pollen trapping experiment from February to August 1945, when unsheltered cans were exposed in the field for 2-3 consecutive weeks, so that they would also collect rain water. They found that the values obtained compared best with those of Welten (1944) from sub-fossil material and suggested that monitoring should ideally be conducted over several years. However, their primary intention of pollen trapping was not to aid in the interpretation of fossil material, but to estimate the production of proteins and fats by trees.

\section{The pollen content of air}

Monitoring the pollen content of the air has become standard practice, and during the flowering season, daily results and forecasts are often part of weather reports to inform those with hay fever. The research on airborne allergenic pollen is part of the field of aerobiology, which as a research topic has a long history, including Pouchet (1860) and Pasteur (1862). However, a specific focus on airborne pollen started only with the discovery of the cause of "summer catarrh", as hay fever used to be called, by the English doctor Charles Blackley (1873). He constructed a roofed impact pollen trap with the microscope slide exposed vertically and a wind vane to orientate the sticky surface against the wind. Thus he was probably the first person to record the occurrence of atmospheric pollen during the flowering season. 
Microscope slides coated with a sticky substance were hence already exposed to the atmosphere before Quaternary palynologists took an interest. However, when European Quaternary palynology took off, there seems to have been an enormous exchange of ideas and results. In contrast, in North America, the research on the pollen content of the air developed before an increased interest in Quaternary palynology and quickly became important (Wodehouse 1935). Durham (1928) published the design of a simple sampler consisting of a coated microscope slide placed between two horizontal metal discs, and suggested a standardised sampling and counting procedure to obtain comparable results (Durham 1946). This sampler was widely used in the USA and similar designs were employed in Europe.

A similar setup was employed by Hyde (1950) in 1943 to sample the atmospheric pollen content at a number of stations throughout England and Wales. In 1952 the English phytopathologist Hirst (1952) published the design of a volumetric sampler, which, with modifications, was produced by Burkard Manufacturing Ltd. and is therefore known as Burkard trap or Hirst sampler. This device is equipped with a vacuum pump that reduces pressure within the sampling chamber. The air is accelerated through a narrow orifice onto a sticky tape covering a drum and the tape is moved forward by clockwork. This type of volumetric air sampler has become the most commonly used sampler in aeropalynology in Europe. In North America the Durham device is only rarely used today, whereas the Rotorod sampler manufactured by Multidata Sampling Technologies has become the most widely used device there (Frenz and Lince 1997). In the Rotorod sampler, small rods coated with a silicone based medium are rotated through the air and the particles impacting on the rods are analysed (DiGiovanni 1998).

In 1974, Cour published the description of an impact sampler consisting of five layers of cellulose gauzes set in a $20 \times 20 \mathrm{~cm}$ frame and mounted on a wind vane, so that the filter would always be perpendicular to the wind (Cour 1974). The gauze is impregnated with silicone oil, creating an adhesive surface for pollen grains, and with the installation of an anemometer at the level of the frame, the amount of pollen in the air can be calculated. The Cour trap is relatively easy to construct and its comparably large surface increases the amount of pollen that is caught. For this reason it is often chosen in regions with thin vegetation cover and therefore little pollen production, such as in the Sahara where it was first applied (Cour and Duzer 1973) or the Tibetan plateau (Cour et al. 1999). The trap may also be effective for studies of the long distance transport of pollen (Rousseau et al. 2006).

\section{Pollen influx versus pollen accumulation rates}

Absolute pollen analytical results are usually referred to as pollen influx or PAR, and there is often confusion over the difference between the two terms. The early history of the two terms provides some insights. With the invention of radiocarbon dating it became possible to estimate sediment accumulation rates of deposits other than varved lake sediments. Consequently Davis and Deevey (1964) carefully sampled and dated the Late-glacial sediments from Rogers Lake, Connecticut USA, established an age-depth model, and estimated absolute pollen deposition. The title of this publication was "Pollen accumulation rates: estimates from Late-Glacial sediment of Rogers Lake", and thus the term pollen accumulation rate (PAR) was coined. In her second publication on the Late-glacial and Holocene sediments from Rogers Lake, Davis (1967) also used the terms "total pollen deposition" and "accumulation rate". However, the term "influx" emerged in the third publication on Rogers Lake (Davis 1969), where Davis stated that E. J. Cushing suggested this term to her. For some reason this term stuck in the heads of Quaternary palynologists and became generally used to describe the amount of pollen in volumes of sediment with known deposition time, as well as that deposited in gravity pollen samplers. The term was criticised as early as 1980 by Thompson (1980) in a letter to the editor of Quaternary Research, where he pointed out that the term was imprecisely used by palynologists. His main argument was that the dimensions of the term are not consistent with those of related properties used in physics. Thompson suggested that the term "influx" should be used as the time integral of flux density (accumulation rate) and expressed in units of volume, mass, or numbers of grains. The term flux may be used in the same way as in physics (grains $\times$ year $^{-1}$ ), but applying it to pollen in lake sediments would require knowledge on the lake surface area, the average sediment accumulation rate and the average pollen concentration in the sediment. Following his argument, the term "flux" as well as his suggested use of the term "influx" could easily be used to describe the amount of pollen caught in a pollen trap, while it would prove difficult to quantify for a lake. He argued that the quantity: "pollen grains $\times$ unit surface ${ }^{-1} \times$ unit time $^{-1}$ " is comparable to the physical quantity of "flux density" and therefore the use of the term "pollen accumulation rate" is preferable, as it had been used in the pioneering article by Davis and Deevey (1964). While palynologists adopted the term "influx" within a few years, they have not fully managed to return to the original term in 30 years, although no arguments defending the term against Thompson's (1980) criticism were found in the available literature. Related to this discussion are studies showing the differential deposition of pollen and sediment 
in lake basins which have recently been summarized by Giesecke and Fontana (2008).

\section{Tauber's pollen trap}

Working in the radiocarbon laboratory of the National Museum in Copenhagen, Denmark, Tauber came in contact with palaeoecologists and took an interest in the transport and deposition of pollen. In 1965 he published his model of pollen dispersion, which built on published concepts of particle transport in the atmosphere and a few results from pollen trapping experiments, among which he made most use of those published by Rempe (1937). In order to test his theory with measurements, he devised a gravity pollen trap, which differs from earlier designs in having an aerodynamic collar (Fig. 1), and installed it both with and without a roof on a raft floating in a small lake within a wood on Sjælland, Denmark (Tauber 1967). The trap, thenceforth named a Tauber trap, quickly became popular among palaeoecologists, who set out to conduct new experiments with it (Berglund 1973; Andersen 1974; Hicks 1974; Bonny 1976), although Tauber only published the detailed description of the design in 1974. Peck (1972) even tested it in a turbulent water flow and conducted a trapping experiment where the trap was used above as well as below the water surface (Peck 1973). In a comparison of Tauber traps with open glass cups without lids, Krzywinski (1977) noted that the Tauber trap lid was at times covered by pollen, and he speculated that this pollen could be washed into the trap by rain drops. He conducted an experiment with coal dust and Corylus pollen, and showed that large quantities of dust and pollen can be transported into the trap by raindrop splash. Bonny and
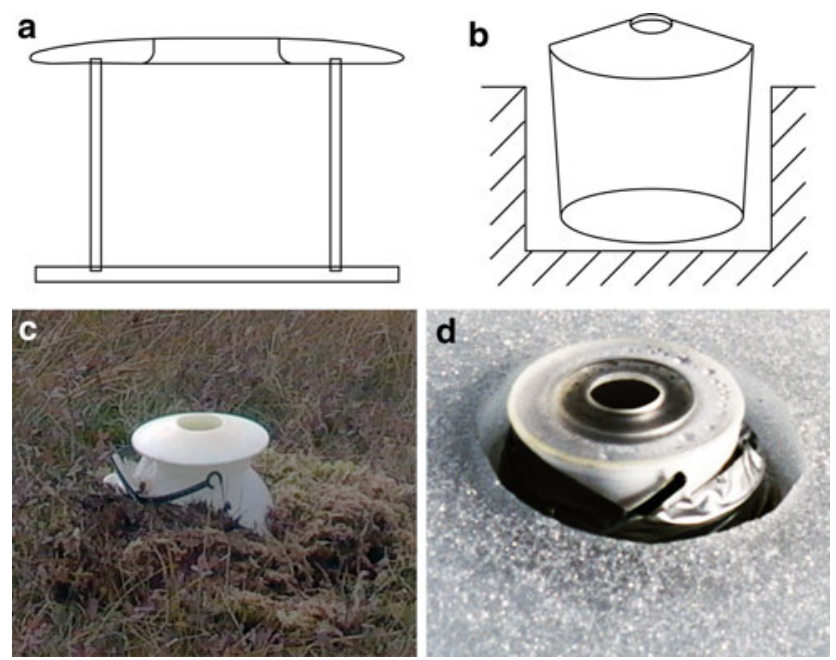

Fig. 1 Comparison of a Tauber's original design (Tauber 1974) to b one modification commonly used within the Pollen Monitoring Programme (PMP; Hicks et al. 2001), and photos of the two trap designs in the field $\mathbf{c}$ with Tauber collar and $\mathbf{d}$ flat sloping lid
Allen (1983) conducted a field experiment to investigate this problem further, but could not find conclusive evidence for the suggested transport of pollen from the lid through splashing rain drops. However, they did find that the average pollen catch was consistently higher in the Tauber trap, but attributed this to a discrepancy in performance between the traps in moving air.

Tauber himself continued pollen trapping experiments over a period of 5 years to test his theoretical model of pollen transport and deposition (Tauber 1977). Andersen (1967, 1970), who at the time worked at the Geological Survey of Denmark, investigated the relationship between pollen proportions in surface samples and the tree composition of a small forest in southern Jylland, Denmark. So it is no surprise that Andersen had already installed traps of Tauber's design in the forest by 1967 (Andersen 1974). What is astonishing is that this monitoring experiment has been kept going, so that this dataset is the longest continuous pollen monitoring record in existence, much to the credit of Peter Friis Møller at the Geological Survey of Denmark and Greenland (Nielsen et al. 2010). Andersen also played a part in the development of tablets with Lycopodium spores (Stockmarr 1971) for 'spiking' samples prior to preparation as a means of estimating pollen concentrations and accumulation rates (Birks 2009). The use of an exotic marker was less time consuming than earlier methods used to establish the absolute pollen content of a sample (Davis 1966) and thus may have helped encourage more trapping experiments. Although Stockmarr's tablets of Lycopodium spores are not the only way of spiking a sample (Bonny 1972), they are the most widely used, because they come as a convenient tablet.

\section{Other modern gravity samplers}

Pollen traps of Tauber's design have been used in different parts of the world and in different vegetation types, such as the Egyptian desert (Ritchie 1986), the prairie of northern Texas (Hall 1992), the Australian rainforest (Kershaw and Strickland 1990), the pampas grassland of Argentina (Majas and Romero 1992), and in Iceland and Svalbard (Hattestrand et al. 2008). However, what is termed a Tauber trap in recent publications is often missing the typical characteristic of Tauber's (1974) design, the aerodynamic lid (Fig. 1). In this respect it is important to note that the standard traps used in the pollen monitoring network (PMP) generally lack the aerodynamic lid, but retain a collar that gently slopes up to a hole in the centre (Fig. 1; Hicks et al. 2001). The traps in the PMP network are generally installed in such a way that the collar is at or slightly above ground level, where wind speeds are low and the aerodynamic effect of the collar is less important. 
With a similar reasoning, Cundill (1986) constructed a pollen trap that was modelled on the pollen collection by a moss surface, so that results from the trap and the moss sample could be compared. He used a flower pot sunk into the ground and with the top covered with acetate wool and a metal mesh. The flower pot drains excess water and the acetate wool imitates a moss surface and traps the pollen. Acetate wool has the advantage that it can be dissolved in acetone to liberate the pollen grains. For this reason acetate fibre had already been used in the pollen trap designed by F. Oldfield and modified and described by Flenley (1973). In this design, the idea was not necessarily to simulate the trapping characteristics of moss, but to cope with the large precipitation in a tropical rainforest. Thus the acetate fibre (de-oiled acetate yarn) was placed on a sintered glass filter sitting in a polythene funnel, which led into a container with an overflow so that water was retained in the container but prevented from rising up into the filter.

Bush (1992) experimented with this design in different environments, which resulted in a modified version. Due to problems in obtaining acetate fibre, and its behaviour in the field and in the laboratory, he used viscose rayon sitting in a glass-fibre filter. In the laboratory, the rayon is dissolved in acetolysis mixture and the glass-fibre filter can be thoroughly washed. Behling et al. (1997) described how the rayon can be washed and squeezed during standard pollen preparation rather than dissolved, and Gosling et al. (2003) showed that this procedure had little influence on the composition and amount of pollen recovered. Gosling et al. (2003) observed that the rayon in Bush's (1992) trap design remained dry even if the bottle was filled with water, and thus argued that the bottle is not necessary. Also, Behling and co-workers have developed a simplified design, consisting of a large centrifuge tube containing some glycerine in the bottom and with rayon squeezed in the top to retain pollen if the tube overflows (Niemann et al. 2009).

Surface samples that represent one or more years of pollen deposition may be difficult to obtain in the tropics in general, and specifically in situations with seasonal flooding such as in the Amazon basin (Gosling et al. 2003). Here pollen traps are important surface samples, which may explain why the results are often only reported as percentages. Little is known about pollen production and deposition in the tropics (Hamilton and Perrott 1980; Meadows 1984), and pollen traps of various designs will surely help to gain more insight.

\section{The Pollen Monitoring Programme}

In contrast to tropical pollen trapping, pollen monitoring in Europe has a long history, the early part of which was reviewed above. Pollen trapping experiments have already yielded insights on several aspects of average pollen deposition, its inter-annual variability, the relationship between the abundance of trees and PAR, and the influence of climatic variability on annual pollen deposition (Andersen 1974, 1980). In more recent years, trapping experiments and long monitoring series from northern Finland have continued to demonstrate the usefulness of this research (Hicks 1985, 2001). Hicks (1994) showed that various vegetation types could be characterised in terms of PAR, the results from which could be used for the interpretation of sub-fossil pollen profiles. Hyvärinen (1975, 1976) presented PAR from small lakes in northern Finland, showing that they could be compared between lakes despite potential problems of re-deposition and sediment focussing. The successful comparisons between these PAR from lake sediments and those from pollen traps (Hicks and Hyvärinen 1999; see also Giesecke and Fontana 2008) may also have stimulated new interest in pollen trapping experiments. Thus the prospect of using the results of pollen monitoring experiments directly to interpret the estimated PAR in sediment cores led, in 1995, to the formation of an INQUA working group to monitor pollen deposition in Europe. The geographical focus was soon broadened to welcome scientists from outside Europe, and

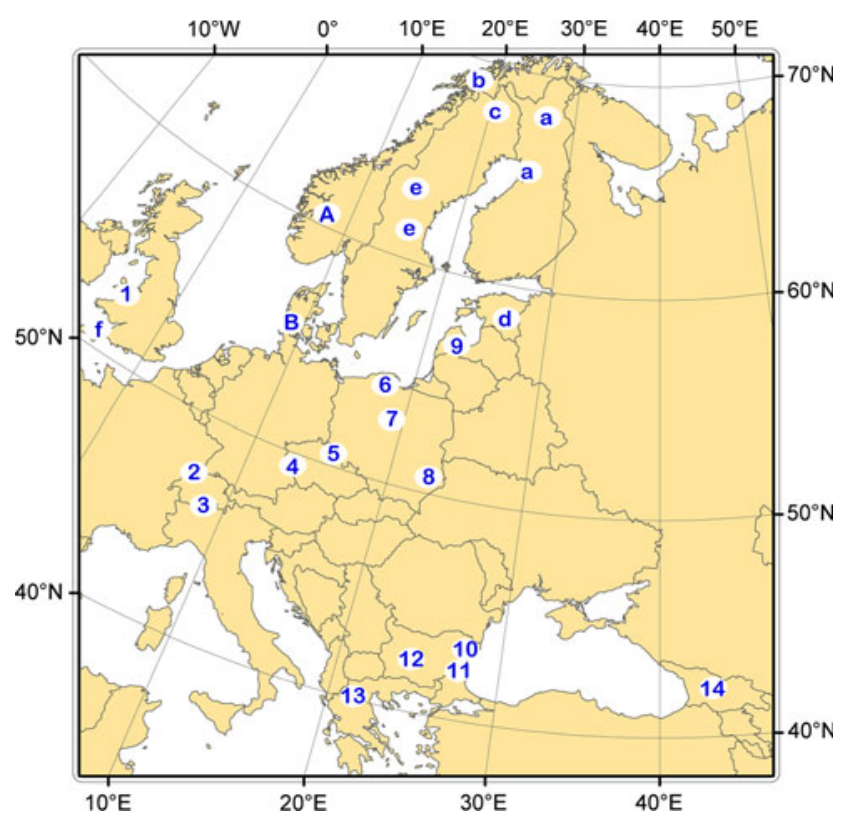

Fig. 2 Distribution of regions with available data on annual pollen deposition as monitored according to the guidelines of the Pollen Monitoring Programme (PMP) in selected parts of Europe and Asia. Numbers mark the regions specified in Table 1. Capital letters indicate the locations of site specific studies $A$ Birks and Bjune (2010) and $B$ Nielsen et al. (2010). Lower case letters mark selected monitoring studies published elsewhere: $a$ Hicks (1985, 1992, 2001); $b$ Jensen et al. (2007); $c$ Hattestrand et al. (2008); $d$ Koff (2001); $e$ Giesecke and Fontana (2008); $f$ Tinsley (2001) 
the group has taken the name "Pollen Monitoring Programme" (PMP). Participants in the programme have set up pollen traps in various regions (Fig. 2) and situations using a standard design of modified Tauber trap (Fig. 1). The group's main activity is the organisation of meetings every 2 or 3 years open to all those interested in pollen trapping experiments. In addition, a website is maintained at http://pmp.oulu.fi and a database stores the results obtained from the standardised experiments.

At the 15th INQUA Congress in 1999, the first Symposium on Modern Pollen Deposition was conducted and a collection of papers from the symposium, together with additional results from the PMP, were collected in a special volume of Review of Palaeobotany and Palynology published in 2001. Within this volume, Hicks et al. (2001) introduced the PMP and its short history and drew together the first tentative observations based on results from the network of standardized pollen traps. Since its beginnings, regular PMP meetings have inspired participants and colleagues to conduct and publish individual pollen trapping experiments or to interrogate individual datasets in new ways (Kvavadze 2001; Räsänen et al. 2004; Fontana 2003; Hicks and Sunnari 2005; Gerasimidis et al. 2006; Pidek 2007; Sjögren et al. 2008; Giesecke and Fontana 2008; Bennett and Hicks 2005; Huusko and Hicks 2009; Sugita et al. 2009; Pidek et al. 2009; Poska and Pidek 2010). The present volume brings together three investigations that combine most of the local and regional pollen trapping experiments to investigate the variation in PAR of Fagus (Pidek et al. 2010), differences in the representation of pollen in moss samples versus pollen traps (Pardoe et al. 2010), and the interaction between inter-annual climate variability and annual pollen deposition (van der Knaap et al. 2010). Filipova-Marinova et al. (2010) estimate pollen productivity based on Bulgarian and Georgian pollen monitoring results, Sjögren et al. (2010) further develop the method of estimating absolute pollen productivity based on Swiss results, Birks and Bjune (2010) compare the trapping of pollen to that of macroscopic plant remains, and Nielsen et al. (2010) present the continuation of Andersen's (1974) trapping experiments. As many of the questions asked in these investigations have already been addressed by Sheila Hicks (Hicks 1999), her long monitoring series from northern Finland were not included in the analyses above. However, more investigations should follow that make use of this large dataset and, of course, include the Finnish results.

\section{PMP trapping regions}

The investigations by Pidek et al. (2010), van der Knaap et al. (2010), Pardoe et al. (2010), Filipova-Marinova et al. (2010), and Sjögren et al. (2010) make use of pollen monitoring results from a number of regions, which are briefly presented below. A summary with details of the different regions is presented in Table 1.

\section{Poland}

Gdańsk region. Four traps are located in the Oliwa forest, part of Trójmiejski landscape park. The forest consists of different associations of Fagus with Pinus, Quercus, Picea, Carpinus and Larix. Communities dominated by Alnus and Ulmus surrounded by patches of Carpinus woodland occur along watercourses.

The Kashubian lake district has a great variety of surface relief, soil and local climate. This is reflected by the diversity of plant communities including Fagus dominated forest, Fagus-Quercus forest with Pinus, Pinus-Betula forest on poor sands, patches of Picea forest, and open areas. Six pollen traps are located in these communities. Pinus and Picea plantations are also widely distributed in the region.

The Tuchola forests include woodlands on the Brda and Wda river outwash plains as well as on moraine islands. Pinus forests dominate vast areas. Three traps are located in Wierzchlas reserve (southeastern Tuchola forests), in Carpinus-Tilia woodland with Taxus and nearby stands of Alnus and Ulmus. In the Taxus Reserve, yew forms the lower tree layer, representing the remains of the Tuchola primeval forest. Six traps are situated in the Zaborski landscape park (western Tuchola forests), in Pinus forest, dry ground forest, mixed forest with Pinus dominance and open landscapes.

Brodnica lakeland. Three traps are located in forest openings and in an open area close to the lake Strażym. Mixed forests and pine woods occupy over $40 \%$ of the area. Subcontinental dry ground forest, composed of Quercus, Tilia, Carpinus and Alnus woods, and riverine forest, is less abundant.

Toruń basin. Las Piwnicki reserve lies in the northern part of an isolated dry ground forest patch with Carpinus, Quercus, Tilia and Pinus. The forest is surrounded on one side by Pinus forests and on the other side by the almost treeless open land in the suburbs of Torun. Alnus dominates a nearby wetland and riverine forest. Two traps are located inside the dry ground forest and on its edge, and a third trap is situated in an open area.

The Roztocze region in south eastern Poland belongs to the middle Polish upland belt. Roztocze national park protects the most natural parts of the forests. Nine pollen traps are located in the national park near the village of Guciów. Here there is a mosaic of plant communities including Abies wood, mixed forest dominated by Fagus, Abies and Pinus, cultivated fields and pure Fagus forest (Pidek 2004). 


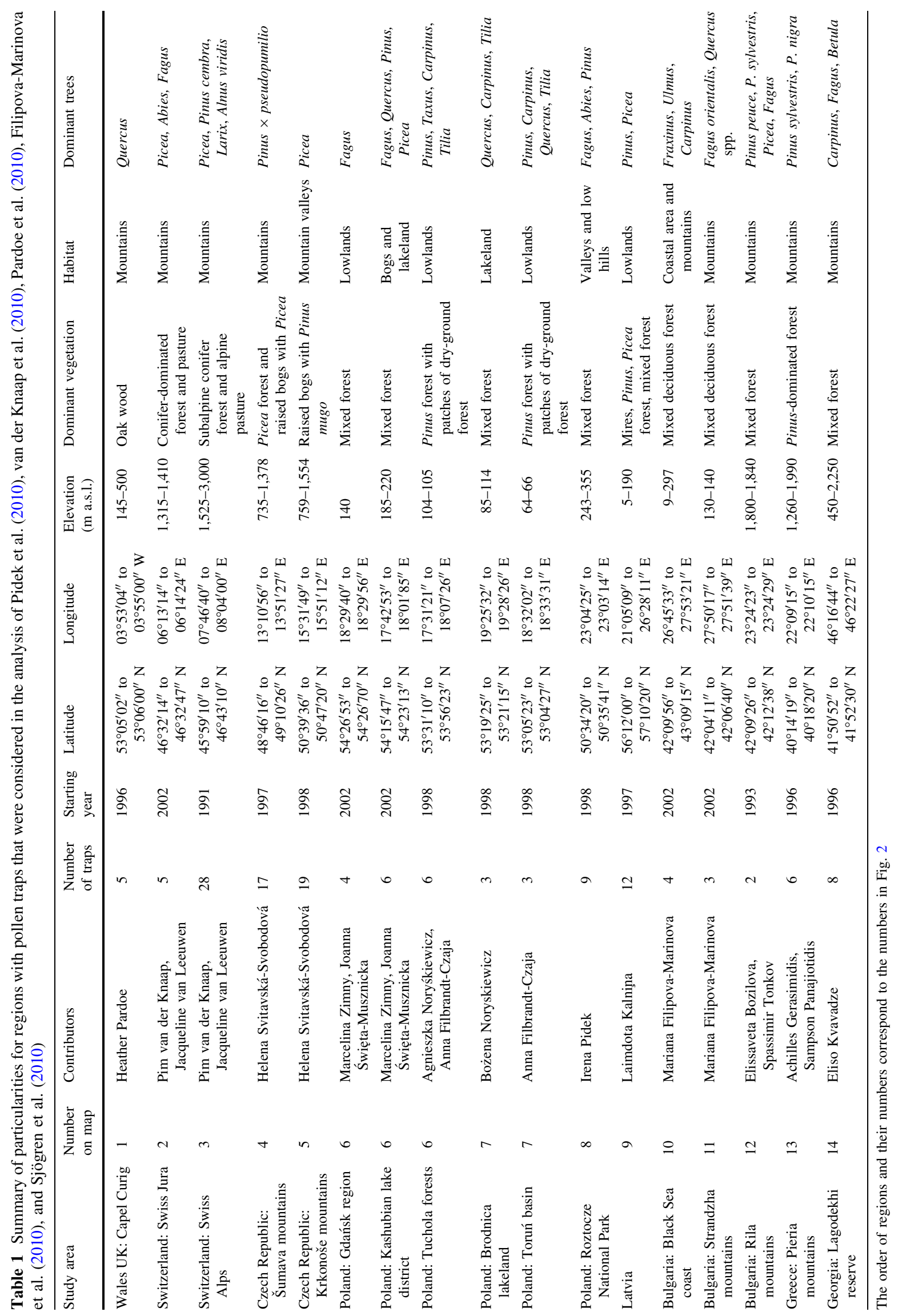




\section{Latvia}

Traps are placed in various landscapes across Latvia ranging from coastal lowlands to semi-continental uplands stretching over a strong gradient in continentality. Due to vandalism, the number of working traps for any given year varies greatly. In 2007 a total of 24 traps were set out in nine regions, while 12 traps in five regions are currently in operation and have yielded results. The traps are often placed in large raised bog complexes (Seda, Teici and Kemeri), and also in small openings and under the tree canopy. Three traps are positioned at the western boundary of the city of Riga in different environments: agricultural land, woodland and raised bog. The most abundant tree near all traps is Pinus sylvestris and Picea abies is common or abundant near most of the traps. Pollen traps near Riga also collect the pollen from several exotic tree species planted in the suburbs of the city.

\section{Czech Republic}

The Krkonoše mountains. These, rising to over $1,500 \mathrm{~m}$, are part of the high Sudetes in the northern outlier of the Bohemian massif. The submontane zone (400-800 m) has broadleaved and mixed forests of Fagus together with Picea and Abies, Acer pseudoplatanus, Fraxinus, Sorbus and Alnus incana. Above this is a pure Picea forest belt. A total of 19 pollen traps are placed within the Picea belt and above the tree line.

The Šumava mountains/Böhmerwald rise to over $1,350 \mathrm{~m}$ and lie on the border of the Czech Republic with Germany and Austria. They have a mosaic of temperate deciduous broadleaved forest, and at higher elevations coniferous forest, as well as peat bogs and open areas. Lower elevations are dominated by acidophilous FagusAbies and herb-rich Fagus forests. Picea woods cover the hilltops above $800 \mathrm{~m}$ and mires occur between $600 \mathrm{~m}$ and the mountain tops. Most of the 18 traps are placed within these mires. Large areas around the mires are dominated by Picea and Sorbus aucuparia, while Pinus rotundata is prevalent on raised bogs.

\section{Switzerland}

The Swiss Jura is part of the large central European Jura mountain range, which stretches from the lower Rhône valley in France along the Swiss-French border into southern Germany. The bedrock is mainly calcareous. The colline zone is dominated by thermophilous deciduous forest with abundant Carpinus, Quercus, Ulmus, Tilia and Fagus. The vegetation in the montane zone consists mainly of Fagus forest. In the sub-alpine zone Picea and Abies increase in abundance with altitude. The five traps are located in this zone.

The Swiss Alps have a highly varied forest composition depending on elevation, distance to the lowlands, local climate and other factors. All pollen traps are placed in the sub-alpine or alpine zone, in the following four regions: Grindelwald (8 traps) in the northern, sub-oceanic Alps, with predominantly Picea forest and the local presence of Pinus cembra and P. mugo; Aletsch (9 traps) in the subcontinental central Alps, with a Pinus cembra-Larix forest belt and a Picea belt above it with the occurrence of Alnus viridis; Simplon (4 traps) with a similar forest composition but mostly open; and Zermatt (5 traps) lying mostly above the tree line, and forests consisting of Pinus cembra and Larix (see van der Knaap et al. 2001).

\section{Greece}

The six traps in the Pieria mountains, northern Greece, are located in an altitudinal transect from 1,200 to 2,000 $\mathrm{m}$ and cover a range of landscapes from forests composed of Pinus sylvestris and/or P. nigra to open sub-alpine communities with dwarf shrubs, mostly Juniperus communis ssp. nana (see Gerasimidis et al. 2006, 2008).

\section{Bulgaria}

The Bulgarian traps are placed in several different regions. Two traps are located in openings in mixed conifer forest in the central Rila mountains, southwestern Bulgaria (see Tonkov et al. 2001). The altitudinal vegetation belts here range from Quercus forests on the lowest slopes, through Fagus forest, coniferous forests, to alpine vegetation on the summits. One trap is on a south facing slope with Pinus peuce, $P$. sylvestris and Picea, the other on a north facing slope with Pinus peuce, Picea and Pinus mugo.

Several traps are situated near the Black Sea coast including one in the vicinity of the Kamchia river estuary, another near Arkutino lake; at both sites Fraxinus oxycarpa and Ulmus minor are important. Three traps are situated in the Strandzha mountains with mesophytic forests dominated by Fagus orientalis, with an understory of Rhododendron ponticum, and a higher proportion of Quercus polycarpa, $Q$. cerris and $Q$. frainetto in drier areas. In the protected valleys of the Preslavska mountains, one trap is located in Aesculus dominated forest with some Juglans, Fraxinus, Carpinus orientalis, Corylus and other trees, and another in mesophytic Cercis dominated woodland.

\section{Georgia}

There are ten pollen traps in the Lagodekhi reserve in the Caucasus mountains, along a 2,000 m altitudinal transect 
on a steep ridge line (Kvavadze 1999, 2001). The vegetation grades from wet forest in the valley dominated by Pterocarya, Alnus barbata, Carpinus betulus and Acer trautvetteri, through forests dominated by Carpinus caucasica and Tilia, higher altitude woods dominated by $\mathrm{Fa}$ gus orientalis and Carpinus caucasica, subalpine woods of Acer velutinum and Betula litwinowii, to an alpine belt where the highest trap is located.

\section{Wales, UK}

The Welsh sites are on the slopes of Moel Siabod, close to Capel Curig. The lowest three traps are in Bryn Engan, a semi-ancient deciduous wood dominated by Quercus petraea, fringed by Corylus and Ilex and with a ground layer of Pteridium and Rubus. Above the wood and on surrounding slopes are plantations of conifers. Two traps are located in heathland, on the upper slopes of Moel Siabod, where Calluna, Vaccinium myrtillus, Erica cinerea and grasses dominate.

Acknowledgements We dedicate this paper to Sheila Hicks. We thank Helena Svitavská-Svobodová, Agnieszka and Bozena Noryśkiewicz, Anna Filbrandt-Czaja, Malgorzata Latałowa, Marcelina Zimny, Joanna Święta-Musznicka, Elissaveta Bozilova, Spassimir Tonkov, Mariana Filipova-Marinova, Eliso Kvavadze, Sampson Panajiotidis, Achilles Gerasimidis, Jacqueline van Leeuwen, Laimdota Kalnina and Simon Connor for information on vegetation. We are grateful to Felix Bittmann and Malgorzata Latałowa for their constructive comments. Helena Svitavská-Svobodová is also acknowledged for supplying a photo of a Tauber pollen trap. This research is part of the Pollen Monitoring Programme PMP (INQUA working group; http://pmp.oulu.fi/) and contributes to the European Union project Millennium - European climate of the last millennium (SUSTDEV-2004-3.1.4.1).

Open Access This article is distributed under the terms of the Creative Commons Attribution Noncommercial License which permits any noncommercial use, distribution, and reproduction in any medium, provided the original author(s) and source are credited.

\section{References}

Aario L (1940) Waldgrenzen und subrezente Pollenspektren in Petsamo Lappland. Annales Academiae Scientiarum Fennicae, Ser A 54:1-120

Andersen ST (1967) Tree-pollen rain in a mixed deciduous forest in South Jutland (Denmark). Rev Palaeobot Palynol 3:267-275

Andersen ST (1970) The relative pollen productivity and pollen representation of north European trees, and correction factors for tree pollen spectra. Danmarks Geologiske Undersøgelse Række II 96:1-99

Andersen ST (1974) Wind conditions, pollen deposition in a mixed deciduous forest. II. Seasonal, annual pollen deposition 1967-1972. Grana 14:64-77

Andersen ST (1980) Influence of climatic variation on pollen season severity in wind-pollinated trees and herbs. Grana 19:47-52

Behling H, Negrelle RRB, Colinvaux PA (1997) Modern pollen rain data from the tropical Atlantic rain forest, Reserva Volta Velha, South Brazil. Rev Palaeobot Palynol 97:287-299
Bennett KD, Hicks S (2005) Numerical analysis of surface and fossil pollen spectra from northern Fennoscandia. J Biogeogr 32:407-423

Berglund BE (1973) Pollen dispersal and deposition in an area of southeastern Sweden—some preliminary results. In: Birks HJB, West RG (eds) Quaternary plant ecology. Blackwell, Oxford, pp 117-129

Bertsch F (1935) Das Pfrungener Ried und seine Bedeutung für die Florengeschichte Südwestdeutschlands. Beihefte Botanisches Zentralblatt 54:185-243

Birks HJB (2009) Svend Th. Andersen (1926-2009). Rev Palaeobot Palynol 157:189-191

Birks HH, Bjune AE (2010) Can we detect a west-Norwegian treeline from modern samples of plant remains and pollen? Results from the DOORMAT project. Veget Hist Archaeobot 19. doi: 10.1007/s00334-010-0256-0 (this volume)

Blackley CH (1873) Experimental researches on the causes and nature of catarrhus aestivus (hay fever or hay asthma). Balliere, London

Bonny AP (1972) A method for determining absolute pollen frequencies in lake sediments. New Phytol 71:393-405

Bonny AP (1976) Recruitment of pollen to the seston and sediment of some Lake District lakes. J Ecol 64:859-887

Bonny AP, Allen PV (1983) Comparison of pollen data from Tauber traps paired in the field with simple cylindrical collectors. Grana 22:51-58

Bush MB (1992) A simple yet efficient pollen trap for use in vegetation studies. Veget Sci 3:275-276

Cour P (1974) Nouvelles techniques de détection des flux et des retombées polliniques: étude de la sédimentation des pollens et des spores à la surface du sol. Pollen Spores 16:103-142

Cour P, Duzer D (1973) Persistance d'un climat hyperaride au Sahara central et méridional au cour de l'Holocène. Rev Géol Dynam Géog Phys 58:175-198

Cour P, Zheng Z, Duzer D, Calleja M, Yao Z (1999) Vegetational and climatic significance of modern pollen rain in northwestern Tibet. Rev Palaeobot Palynol 104:183-204

Cundill PR (1986) A new design of pollen trap for modern pollen studies. J Biogeogr 13:83-98

Davis MB (1966) Determination of absolute pollen frequency. Ecology 47:310-311

Davis MB (1967) Pollen accumulation rates at Rogers Lake Connecticut USA during late and post glacial time. Rev Palaeobot Palynol 2:219-230

Davis MB (1969) Climatic changes in southern Connecticut recorded by pollen deposition at Rogers Lake. Ecol 50:409-422

Davis MB (2000) Palynology after Y2K-understanding the source area of pollen in sediments. Ann Rev Earth Planet Sci 28:1-18

Davis MB, Deevey ES (1964) Pollen accumulation rates-estimates from late-glacial sediment of Rogers Lake. Science 145:1,293-1,295

Davis MB, Brubaker LB, Webb T (1973) Calibration of absolute pollen influx. In: Birks HJB, West RG (eds) Quaternary plant ecology. Blackwell, Oxford, pp 9-25

Di-Giovanni F (1998) A review of the sampling efficiency of rotatingarm impactors used in aerobiological studies. Grana 37:164-171

Durham OC (1928) Contribution of air analysis to the study of allergy. Lab Clin Med 13:967-976

Durham OC (1946) The volumetric incidence of airborne allergens. IV. A proposed standard method of gravity sampling, counting and volumetric interpretation of results. Allergy 17:79-86

Erdtman G (1937) Pollen grains recovered from the atmosphere over the Atlantic. Meddelanden från Göteborgs Botaniska Trädgård 12:185-196

Erdtman G (1943) An introduction to pollen analysis. Chronica Botanica, Waltham, Mass 
Filipova-Marinova MV, Kvavadze EV, Connor SE, Sjögren P (2010) Estimating absolute pollen productivity for some European Tertiary-relict taxa. Veget Hist Archaeobot 19. doi:10.1007 /s00334-010-0257-z (this volume)

Firbas F, Sagromsky H (1947) Untersuchungen über die Größe des jährlichen Pollenniederschlags vom Gesichtspunkt der Stoffproduktion. Biologisches Zentralblatt 66:129-140

Flenley JR (1973) The use of modern pollen rain samples in the study of the vegetational history of tropical regions. In: Birks HJB, West RG (eds) Quaternary plant ecology. Blackwell, Oxford, pp 131-141

Fontana SL (2003) Pollen deposition in coastal dunes, south Buenos Aires Province, Argentina. Rev Palaeobot Palynol 126:17-37

Frenz DA, Lince NL (1997) A comparison of pollen recovery by three models of the Rotorod sampler. Ann Allergy Asthma Immunol 79:256-258

Gerasimidis A, Panajiotidis S, Hicks S, Athanasiadis N (2006) An eight-year record of pollen deposition in the Pieria Mountains ( $N$ Greece) and its significance for interpreting fossil pollen assemblages. Rev Palaeobot Palynol 141:231-243

Gerasimidis A, Panajiotidis S, Athanasiadis N (2008) Five decades of rapid forest spread in the Pieria Mountains (N. Greece) reconstructed by means of high-resolution pollen analysis and aerial photographs. Veget Hist Archaeobot 17:639-652

Giesecke T, Fontana SL (2008) Revisiting pollen accumulation rates from Swedish lake sediments. Holocene 18:293-305

Gosling WD, Mayle FE, Killeen TJ, Siles M, Sanchez L, Boreham S (2003) A simple and effective methodology for sampling modern pollen rain in tropical environments. Holocene 13:613-618

Hall SA (1992) Comparative pollen influx at a 9-trap array in the grand prairie of northern Texas. Tex J Sci 44:469-474

Hamilton AC, Perrott RA (1980) Modern pollen deposition on a tropical African Mountain. Pollen Spores 22:437-468

Hattestrand M, Jensen C, Hallsdottir M, Vorren KD (2008) Modern pollen accumulation rates at the north-western fringe of the European boreal forest. Rev Palaeobot Palynol 151:90-109

Hesselman H (1916) Yttrande med anledning av L. von Post's föredrag: "Om skogsträdpollen i sydsvenska torfmosselagerföljder". Geologiska Föreningens i Stockholm Förhandlingar 38:390-392

Hesselman H (1919a) Om pollenregn på hafvet och fjärrtransport af barrträdspollen. Geologiska Föreningens i Stockholm Förhandlingar 41:89-99

Hesselman H (1919b) Über die Verbreitungsfähigkeit des Waldbaumpollens. Meddelanden från Statens Skogsförsökanstalt $16: 27-66$

Hicks S (1974) A method of using modern pollen rain values to provide a timescale for pollen diagrams from peat deposits. Memorana Societas Fauna Flora Fennica 49:21-33

Hicks S (1985) Modern pollen deposition records from Kuusamo, Finland. 1. Seasonal and annual variation. Grana 24:167-184

Hicks S (1992) Modern pollen deposition and its use in interpreting the occupation history of the island Hailuoto, Finland. Veget Hist Archaeobot 1:75-86

Hicks S (1994) Present and past pollen records of Lapland forests. Rev Palaeobot Palynol 82:17-35

Hicks S (1999) The relationship between climate and annual pollen deposition at northern tree-lines. Chemosphere 1:403-416

Hicks S (2001) The use of annual arboreal pollen deposition values for delimiting tree-lines in the landscape and exploring models of pollen dispersal. Rev Palaeobot Palynol 117:1-29

Hicks S, Hyvärinen H (1999) Pollen influx values measured in different sedimentary environments and their palaeoecological implications. Grana 38:228-242

Hicks S, Sunnari A (2005) Adding precision to the spatial factor of vegetation reconstructed from pollen assemblages. Plant Biosyst 139:127-134
Hicks S, Tinsley H, Huusko A, Jensen C, Hattestrand M, Gerasimides A, Kvavadze E (2001) Some comments on spatial variation in arboreal pollen deposition: first records from the Pollen Monitoring Programme (PMP). Rev Palaeobot Palynol 117:183-194

Hirst JM (1952) An automatic volumetric spore trap. Ann Appl Biol 39:257-265

Huusko A, Hicks S (2009) Conifer pollen abundance provides a proxy for summer temperature: evidence from the latitudinal forest limit in Finland. Quat Sci 24:522-528

Hyde HA (1950) Studies in atmospheric pollen. IV. Pollen deposition in Great Britain, 1943. II. The composition of the pollen catch. New Phytol 49:405-418

Hyvärinen H (1975) Absolute and relative pollen diagrams from northernmost Fennoscandia. Fennia 142:1-23

Hyvärinen H (1976) Flandrian pollen deposition rates and tree-line history in northern Fennoscandia. Boreas 5:163-175

Jensen C, Vorren K-D, Mørkved B (2007) Annual pollen accumulation rate (PAR) at the boreal and alpine forest line of northwestern Norway, with special emphasis on Pinus sylvestris and Betula pubescens. Rev Palaeobot Palynol 144:337-361

Kershaw AP, Strickland KM (1990) A 10 year pollen trapping record from rainforest in northeastern Queensland, Australia. Rev Palaeobot Palynol 64:281-288

Knoll F (1932) Über die Fernverbreitung des Blütenstaubes. Forschung und Fortschritt 8:301-302

Koff T (2001) Pollen influx into Tauber traps in Estonia in 1997-1998. Rev Palaeobot Palynol 117:53-62

Krzywinski K (1977) The Tauber pollen trap, a discussion of its usefulness in pollen deposition studies. Grana 16:147-148

Kvavadze E (1999) The first results of the pollen monitoring programme in the Caucasus Mountains (Georgia). Acta Palaeobot 39:171-177

Kvavadze E (2001) Annual modern pollen deposition in the foothills of the Lagodekhi Reservation (Caucasus, East Georgia), related to vegetation and climate. Acta Palaeobot 41:355-364

Lüdi W (1937a) Beitrag zum Problem des Heufieberschutzes in einem Hochtale der Schweizeralpen. Jahresbericht des Heufieberbundes 39:3-15

Lüdi W (1937b) Die Pollensedimentation im Davoser Hochtale. Bericht über das Geobotanische Forschungsinstitut Rübel in Zürich für das Jahr 1936:107-127

Lüdi W, Vareschi V (1936) Die Verbreitung, das Blühen und der Pollenniederschlag der Heufieberpflanzen im Hochtale von Davos. Bericht über das Geobotanische Forschungsinstitut Rübel in Zürich für das Jahr 1935:47-111

Majas FD, Romero EJ (1992) Aeropalynological research in the northeast of Buenos-Aires province, Argentina. Grana $31: 143-156$

Malmström C (1923) Degerö Stormyr-en botanisk, hydrologisk och utvecklingshistorisk undersökning över ett nordsvenskt myrkomplex. Meddelanden från Statens Skogsförsöksanstalt 20, Stockholm

Meadows ME (1984) Contemporary pollen spectra and vegetation of the Nyika Plateau, Malawi. Biogeogr 11:223-233

Miquel P (1883) Les organismes vivants de l'atmosphère. GauthierVillars, Paris

Nielsen AB, Møller PF, Giesecke T, Stavngaard B, Fontana SL, Bradshaw RHW (2010) The effect of climate conditions on inter-annual flowering variability monitored by pollen traps below the canopy in Draved Forest, Denmark. Veget Hist Archaeobot 19. doi:10.1007/s00334-010-0253-3 (this volume)

Niemann H, Brunschön C, Behling H (2009) Vegetation/modern pollen rain relationship along an altitudinal transect between 1,920 and 3,185 $\mathrm{m}$ a.s.l. in the Podocarpus National Park region, southeastern Ecuadorian Andes. Rev Palaeobot Palynol 159:69-80 
Pardoe H, Giesecke T, van der Knaap WO, Svitavská-Svobodová H, Kvavadze E, Panajiotidis S, Gerasimidis A, Pidek IA, Zimny M, Święta-Musznicka J, Latałowa M, Noryśkiewicz AM, Bozilova E, Tonkov S, Filipova-Marinova M, van Leeuwen JFN, Kalninga L (2010) Comparing pollen spectra from modified Tauber traps and moss samples: examples from a selection of woodlands across Europe. Veget Hist Archaeobot 19. doi:10.1007/s00334$010-0258$-y (this volume)

Pasteur L (1862) Examen au microscope des particules disséminées dans l'air atmosphérique. Annales de chimie et de physique. 3e sér 64:5-110

Peck RM (1972) Efficiency tests on the Tauber trap used as a pollen sampler in turbulent water flow. New Phytol 71:187-198

Peck RM (1973) Pollen budget studies in a small Yorkshire catchment. In: Birks HJB, West RG (eds) Quaternary plant ecology. Blackwell, Oxford, pp 43-60

Pidek IA (2004) Preliminary results of pollen trapping in the region of the Roztocze National Park (SE Poland). Annales Univ. M. Curie-Sklodowska sect. B 49:143-159

Pidek IA (2007) Nine-year record of Alnus pollen deposition in the Roztocze region (SE Poland) with relation to vegetation data. Acta Agrobot 60:57-64

Pidek IA, Piotrowska K, Kaszewski BM, Kalnina L, WeryszkoChmielewska E (2009) Airborne birch pollen in Poland and Latvia in the light of data obtained from aerobiological monitoring and Tauber traps in relation to mean air temperature. Acta Agrobot 62:77-90

Pidek IA, Svitavská-Svobodová H, van der Knaap WO, Noryśkiewicz A, Filbrandt-Czaja A, Noryśkiewicz B, Latałowa M, Zimny M, Święta-Musznicka J, Bozilova E, Tonkov S, Filipova-Marinova M, Poska A, Giesecke T, Gikov A (2010) Variation in annual pollen accumulation rates of Fagus along a N-S transect in Europe based on pollen traps. Veget Hist Archaeobot 19. doi: 10.1007/s00334-010-0248-0 (this volume)

Pohl F (1933) Freilandversuche zur Bestäubungsökologie der Stieleiche. Beihefte zum Botanischen Zentralblatt 51:673-692

Poska A, Pidek IA (2010) Pollen dispersal and deposition characteristics of Abies alba, Fagus sylvatica and Pinus sylvestris, Roztocze region (SE Poland). Veget Hist Archaeobot 19:91-101

Pouchet FA (1860) Corps organisés recueillis dans l'air par les flocons de neige. Les Comptes Rendus de l'Académie des Sciences 50:532-534

Räsänen S, Hicks S, Odgaard BV (2004) Pollen deposition in mosses and in a modified 'Tauber trap' from Hailuoto, Finland: what exactly do the mosses record? Rev Palaeobot Palynol 129:103-116

Rempe H (1937) Untersuchungen über die Verbreitung des Blütenstaubes durch die Luftströmungen. Planta 27:93-147

Ritchie JC (1986) Modern pollen spectra from Dakhleh-oasis, western Egyptian desert. Grana 25:177-182

Rousseau DD, Schevin P, Duzer D, Cambon G, Ferrier J, Jolly D, Poulsen U (2006) New evidence of long distance pollen transport to southern Greenland in late spring. Rev Palaeobot Palynol 141:277-286

Scamoni A (1949) Beobachtungen über den Pollenflug der Kiefer und Fichte. Forstwissenschaftliches Centralblatt 68:735-751
Scamoni A (1955) Beobachtungen über den Pollenflug der Waldbäume in Eberswalde. Zeitschrift für Forstgenetik und Forstpflanzenzüchtung 4:113-122

Seppä H, Hicks S (2006) Integration of modern and past pollen accumulation rate (PAR) records across the arctic tree-line: a method for more precise vegetation reconstructions. Quat Sci Rev 25:1501-1516

Sjögren P, van der Knaap WO, Huusko A, van Leeuwen JFN (2008) Pollen productivity, dispersal, and correction factors for major tree taxa in the Swiss Alps based on pollen-trap results. Rev Palaeobot Palynol 152:200-210

Sjögren P, Connor SE, van der Knaap WO (2010) The development of composite pollen-dispersal functions for estimating absolute pollen productivity in the Swiss Alps. Veget Hist Archaeobot 19. doi:10.1007/s00334-010-0247-1 (this volume)

Stockmarr J (1971) Tablets with spores used in absolute pollen analysis. Pollen Spores 13:615-621

Sugita S, Hicks S, Sormunen H (2009) Absolute pollen productivity and pollen-vegetation relationships in northern Finland. J Quat Sci. doi: $10.1002 /$ jqs. 1349

Tauber H (1965) Differential pollen dispersion and the interpretation of pollen diagrams. Danmarks Geologiske Undersøgelse. II Række 89:1-69

Tauber H (1967) Investigations of the mode of pollen transfer in forested areas. Rev Palaeobot Palynol 3:277-286

Tauber H (1974) A static non-overload pollen collector. New Phytol 73:359-369

Tauber H (1977) Investigations of aerial pollen transport in a forested area. Dansk Botanisk Arkiv 32:1-121

Thompson R (1980) Use of the word influx in paleolimnological studies. Quat Res 14:269-270

Tinsley H (2001) Modern pollen deposition in traps on a transect across an anthropogenic tree-line on Exmoor, southwest England: a note summarizing the first three years of data. Rev Palaeobot Palynol 117:153-156

Tonkov S, Hicks S, Bozilova E, Atanassova J (2001) Pollen monitoring in the Central Rila Mts., Southwestern Bulgaria: case studies from pollen traps, surface samples for the period 1994-1999. Rev Palaeobot Palynol 117:167-182

Van der Knaap WO, van Leeuwen JFN, Ammann B (2001) Seven years of annual pollen influx at the forest limit in the Swiss Alps studied by pollen traps: relations to vegetation and climate. Rev Palaeobot Palynol 117:31-52

Van der Knaap WO, van Leeuwen JFN, Svitavská-Svobodová H, Pidek IA, Kvavadze E, Chichinadze M, Giesecke T, Kaszewski BM, Oberli F, Kalnina L, Pardoe H, Tinner W, Ammann B (2010) Annual pollen traps reveal the complexity of climatic control on pollen productivity in Europe and the Caucasus. Veget Hist Archaeobot 19. doi:10.1007/s00334-010-0250-6 (this volume)

Von Post L (1918) Skogsträdpollen i sydsvenska torvmosselagerföljder.-Forhandlinger ved de 16. Skandinaviske Naturforskeresmøte 1916:433-465

Welten M (1944) Pollenanalytische, stratigraphische und geochronologische Untersuchungen aus dem Faulenseemoos bei Spiez. Veröffentlichungen Geobotanisches Institut Rübel 21:1-201

Wodehouse RP (1935) Pollen grains. McGraw Hill, New York 